\title{
Relation of Coordination Eye-Foot with Shooting Precision in Soccer Games
}

\author{
Basiran Basiran, Ridha Mustaqim* \\ Faculty of Sport and Health Education \\ Universitas Pendidikan Indonesia \\ Bandung, Indonesia \\ *ridhamustaqim@upi.edu
}

\begin{abstract}
This study aims to determine the many eye-foot relation to the accuracy of shooting. Often there is an error when shooting. The method taken from this research is descriptive correlative. The population of this research was 15 athletes of SSB AC-GARIS U-17 as many as 15 people with total sampling technique. The instrument used in the Soccer Wall Volley test that tests and tests the target ball. This study consists of two variables, $(X)$ ankle coordination and $(Y)$ shooting accuracy. The functions of the eye-foot with the accuracy of shooting at SSB AC-GARIS athlete U-17 are found on average at low levels. The result of research no relation because a sample of 15 poor people is currently working on the test. And this shows that the ability of the sample is not good and then for next research for athlete Football U-17 can train again continuously.
\end{abstract}

Keywords-coordination; accuracy of eye foot; soccer

\section{INTRODUCTION}

In this modern era, the development of science and technology is growing by leaps and bounds for the sake of the progress of human civilization. Football did not escape from that change, the day football is increasingly changing, be it in terms of how to play, practice, methods of training process. Satriya explains that, "the Exercise is repeated, systematic workload increasingly growing day" [1].

With the exercises for children will add motion or dictionary skills in playing football so gradually that movement will be automation and reflective. Exercises should be done to the maximum load and accompanied exercise that increases every day so the process is increasingly heavy. Football in Indonesia itself has become entertainment for the public at large it is visible from many people play soccer well in villages or urban areas. Views of the role of the audience that watched football at the stadium as well as through television it is really quite remarkable. The game of football is a sport played by two teams, each team consists of 11 players.

As for the main purpose of the game of football is every team or squad tried to enter the ball to the opponent and defend its own entrance so as not to pass the ball. As described by Sucipto et al. explains that: "each of the squad tried to enter as many balls into the opponent and defend the pass itself to no entry" [2].
With that explanation has been very clear that kicks in football matches are very important. Related thereto that, "kicking the ball is the dominant motion patterns are most important in the game of football [2]. Basically playing soccer was kicking the ball, and precision shooting is very important so that every player every opportunity could be the deciding goal in a game of victory.

Lots of factors that support the accuracy of the shooting. One eye-foot coordination, eye-foot coordination is one physical ability is very influential in the game of football. Many movements in football that requires coordination and the coordination is one eye-foot coordination. Such coordination is fundamental to achieve a high skill in playing football. According to Suharno, "Coordination is the ability of athletes to link several motion elements into one movement intact and aligned" [3]. And without exception in the accuracy shooting eye-foot coordination, greatly assist in the placement of the object (ball) who kicked with the direction of placement into the goal.

Someone who has the ability to co-ordinate eye-nice legs no doubt will do the shooting ball into difficult points facing the goalkeeper the ball, because the object that will kicked (the ball) and the goal against is definitely accurate and tough guard intercepted the goal. Sukatamsi states that kicking is the most widely performed activities in the game of football [4]. A player cannot master the kicking well, not going to be a good player. The Club is the club that all players mastered the kick the ball properly. Remember the most important factor is 7 kicked off and the football game then it is to be a good player, the player needs to develop proficiency in kicking. A good kicking in football games require the ability to estimate distance and direction where the ball must be delivered.

Therefore, a player who will kick the ball should estimate the extent to which his shot and the ball was kicked toward which destination will be. So a player next to master the basic techniques of kicking should also have a strong foot in order to obtain the results kick with the desired distance and direction [5].

A good football team is a team that all players mastered the kick the ball properly. Remember the most important factor is kicking in football games and then to become a good player, the player needs to develop proficiency in kicking. A good 
kicking in football games require the ability to estimate distance and direction where the ball must be delivered. Therefore, a player who will kick the ball should estimate the extent to which his shot and the ball was kicked toward which destination will be. So a player next to master the basic techniques of kicking should also have a strong foot in order to obtain the results kick with the desired distance and direction [5].

Accuracy is affected by various factors both internal and external. Internal factors are factors that originate from within 8 subject so it can be controlled by the subject. External factors influenced from outside the subject, and cannot be controlled by the subject himself. According to Sukadiyanto, there are several factors that affect precision, among others: the level of difficulty, experience, previous skills, the kind of skill, feelings, and the ability to anticipate the motion [6]. The factors that determine the accuracy is the factor that comes from within oneself (internal) and factors that come from outside of one's self (external). Internal factors among other skills (strong weak coordination, fast movement, slow movement, a mastery of technique, the ability to anticipate the motion), and feeling (feeling, precision, sharpness of senses). As for external factors, among others, the level of difficulty (the great small target, distance), and the State of the environment.

Soccer is a sport that requires a skill proficiency level is very high. Due to techniques, will simplify the process of creating the player in goal in a game of football. In modern times, the football match broadcast on television very interesting watch because the techniques on display is very attractive and entertaining. Soccer is not just the physical but train various aspects which support CNRT's sports achievement which must be trained to the athletes.

According to Harsono, exercise is an exercise technique to the more advanced techniques of movement committed athletes [7]." The intent of this exercise was provided to train movements that existed in the previous match. Exercise techniques aim to form the motor movement and the nervous system so that later have become accustomed. Exercise techniques will ultimately support the development of tactics in the game of football.

Students who attend training in SSB application tactics should be taught as early as possible, so that they get a stimulus in the interpretation of playing football and of course will train the student intelligentsia. Basically playing soccer is emphasizing cooperation, and cooperation should be done when getting the ball and without the ball.

Luxbacher, says that: A player is required to play nice, able to deal with the pressures that occur in the match above the narrow field with limited time, not to mention the physical fatigue and a formidable sparring opponents [8]. Knowledge of tactics and strategy are therefore very important.

A prospective professional players have above average technique, have a superior physical ability among other players, and has a good tactical ability but have bad attitudes will affect his performance in the performance the field. A successful soccer players are those that can have a fourth aspect is above average. Leonel Messi despite having smaller posture, but he has the advantage in skill, tactical and physical as well as mental good that support performance field.

Eye-foot coordination is the physical condition is very supportive and played an important role in the game of football. In the game of football, it takes a confident view in anticipation of the ball and the precision of the move to kick the ball fits the expected target.

In improving the accuracy of shooting in the game of football is not only influenced by the application of the model or type of exercise the appropriate exercise alone, but of the individual factors are also very influential towards the skills learned. According to Rusli Lutan, that: "Mastering motor skills in sport is influenced by the skill that every person, whether physical or psychological in nature [9].

The function of this research is to provide a description of the data and to develop the techniques of shooting in the game of football. It is associated with the strategy of attack when the ball enters the opponent's defense area then the player must carefully utilize the chance occurrence of a goal by doing the shooting. In several occasions gained when attacking the opposing team, it is often an error occurred in the completion of especially when players did shooting the ball moves or is not controlled, then the player difficulty then balls to the goal.

By doing this research then we will know the relationship coordination of eye-feet with precision shooting. Based on explanation above can be drawn in the form of the statement that the football requires a good shooting techniques in order to maximize completion strategy goals scored.

\section{METHOD}

The design used in this study is correlative descriptive. Descriptive research is research that is intended to investigate the circumstances, conditions or things already mentioned, the results are presented in the form of research reports [10].

Then about the technique of correlative, this conducted by researchers to find out the degree of relationship between two or more variables, without making any changes, additions or manipulation of the data that is There is already [10]. Next, the researchers sampled 15 athletes SSB AC- GARIS U-17 Kab. Bandung.

The instrument used in this research is to Test the coordination of eye and a legs and shooting Precision Test, to measure eye and foot coordination degree of the author using an instrument that modifies from soccer wall volley test [11].

In practice the ball kick into the wall before replaced by the way in juggling, this is done so that the testing in accordance with the characteristics of the game. Before the instrument was used in the testing, the authors advance the instrument to test the different samples. From the results of tests of the validity of the level of known instruments 0.896 dan reliabilities of 0.734 . Eye and foot coordination data retrieved from a modification of the soccer wall volley test. The equipment used was a ball and a stopwatch. 
Next, to the way testing (a) ball juggling for 20 seconds, if the ball falls down then it is first touch not counted; (b) a Juggling ball shall not exceed the knee; (c) if the ball is arrested by hand then it will reduce the points on one; (d) the opportunity of performing the test three times, and the best is to be taken; (e) the assessment test is the number of juggling test done during 20 seconds.

Instrument test is done to measure the accuracy shooting, shoot the ball to the target already determined as much as 3 times then the results aggregated. The tests used in this study is test fired the ball to the target [12].

This test aims to measure ability and prowess of shooting the ball into the goal. The purpose of measuring the accuracy of the kick, the equipment used was the ball, meter, net, rope, numbers.

Implementation instructions (1) Testi stands behind the ball that is placed at a point which is 16.5 meters in front of goal/target; (2) after obtaining the aba aba-testi doing the kick; (3) Testi given 3 times a chance; (a) Score: when a ball kick balls about results of rope or line dividing the score on target, then the second largest of the scores taken goal.

\section{RESULTS AND DISCUSSION}

Analysis on the ability of the eye and foot coordination as well as the precision shooting students, test data is used to see the relationship between the two. Results of the test the ability of the eye and foot coordination as well as the accuracy of the shooting of the students as well as the description criteria of the students ' ability in accordance the norm in previous chapters.

On the ability of the eye and foot coordination, criteria of students ' ability obtained i.e. 7 students is very low, 2 students, 1 student quite good students, 2, and 3 students. Later on the ability of the precision shooting, the criteria of students ' ability obtained i.e. 1 students is very less, 2 students less, 8 students were, 2 students and 2 students very well. Based on the picture look that both data have relationships.

Normality test done to see if the second test data come from a Gaussian population or not. Test of normality that is used in this research is to test the Shapiro Wilk. As for the hypothesis test is as follows.

$\mathrm{H}_{0}$ : Sample test data eye-foot coordination/precision shooting comes from Gaussian populations.

$\mathrm{H}_{1}$ : Sample data to test the coordination of eyefoot/precision shooting comes from Gaussian population.

By using the $5 \%$ significance level $(\alpha=0.05)$ then done criteria is as follows.

$\mathrm{H}_{0}$ is accepted if the value of an $(\mathrm{Sig}) \geq 0.05$.

$\mathrm{H}_{0}$ is rejected if the value of their significance $(\mathrm{Sig})<0.05$.

The following is a table of data normality test results test the ability of the eye and foot coordination as well as the accuracy of shooting.
TABLE I. TEST RESUlt Data Normality TEST Eye-FoOt COORDINATION AND PRECISION SHOOTING

\begin{tabular}{|c|l|l|l|}
\hline The ability of the & \multicolumn{3}{|c|}{ Shapiro-Wilk } \\
\cline { 2 - 4 } & Statistic & \multicolumn{1}{c|}{ Sig. } \\
\hline $\begin{array}{c}\text { Eye-Foot } \\
\text { Coordination }\end{array}$ & 0,943 & 1 & 0,421 \\
\hline $\begin{array}{c}\text { Precision } \\
\text { Shooting }\end{array}$ & 0,957 & 1 & 0,632 \\
\hline
\end{tabular}

Based on the above Data is obtained that the value data of significance test of the ability of the eye and foot coordination is the ability and precision shooting 0.421 is 0.632 . This shows that good coordination ability of the eye and leg as well as the accuracy of the shooting has a value that is more than 0.05 significance that causes $\mathrm{H} 0$ are received. This means that both samples the data comes from a Gaussian population. Since both data test Gaussian, then performed advanced testing i.e. correlation test.

Test the correlation between these two variables in this coordination ability of the eye and leg as well as the capability of precision shooting is done to find out if the data obtained have a significant relationship or not. Testing the correlation of test data using the formula Pearson Product Moment 20.0 SPSS program for Windows with the formulation of a hypothesis as follows.

$\mathrm{H}_{0}$ : there was no significant relationship between eye-foot coordination ability with precision shooting.

$\mathrm{H}_{1}$ : there is a significant relationship between eye-foot coordination ability with precision shooting.

Significant extent used is $5 \%(\alpha=0.05)$ done with the criteria as follows:

- $\mathrm{H}_{0}$ is accepted if the value of significance $(\mathrm{Sig}) \geq 0.05$.

- $\mathrm{H}_{0}$ is rejected if the value of their significance $(\mathrm{Sig})<$ 0.05 .

The following is a table of test data correlation test results on the ability of the eye and foot coordination as well as the capability of precision shooting

TABLE II. PEARson Correlation Test Results Test DAta EyeFOOT COORDINATION AND PRECISION SHOOTING

\begin{tabular}{|c|c|c|c|c|}
\hline Result & r & Pearson & Sig. & H0 \\
\hline Test & & 0,591 & 0,020 & Reject \\
\hline
\end{tabular}

Pearson Correlation test results based on the Data of the eye-foot Coordination Test and precision Shooting in mind that great correlation between eye coordination ability Pearson and feet as well as the capability of precision shooting is 0.591 . The correlation degree pertained to the criteria are. Significance value obtained is 0.020 . Because of the significance value smaller than $\alpha=0.05$ then $\mathrm{H} 0$ is rejected. So it can be concluded that there is a significant relationship between eyefoot coordination ability with precision shooting with criteria including relationships are. 


\section{A. Coefficient of Determination}

To know the predictions of how big the influence given the coordination of eye and walk towards the accuracy shooting in football games used the formula of the determination that is as follows:

$$
\mathrm{D}=\mathrm{r}^{2} \times 100 \%
$$

Description:

\section{$\mathrm{D}=$ Determination}

$\mathrm{r}=$ correlation coefficient

\section{$100 \%=$ Fixed constants}

After doing the calculations, with Pearson correlation degree of determination coefficient obtained 0.591 amounted to $34.93 \%$. Thus, it can be concluded that the influence given the coordination of eye and walk towards the accuracy shooting i.e. amounted to $34.93 \%$.

\section{CONCLUSION}

Based on the results of the data processing, data analysis and discussion of chapter IV on the relationship coordination of eye-leg with accuracy shooting sport soccer branch obtained the following conclusions: (1) there is no significant relationship eye-foot coordination ability with precision shooting in football games due to sample as many as 15 people most categories are at the time of the test. And this shows that the ability of less good samples should be trained on an ongoing basis.
It can be seen from the value of the pearson correlation. This shows that the eye-foot coordination is the higher, then the better the player shooting accuracy. Thus the higher the accuracy shooting the player more chance occurrence.

\section{REFERENCES}

[1] Satriya, Modul Metodologi Kepelatihan Olahraga. Bandung: PKO FPOK UPI Bandung, 2007.

[2] Sucipto, Sepakbola. Pendidikan Departemen dan Kebudayaan, 2000.

[3] H.P. Suharno, Ilmu Kepelatihan Olahraga. Bandung: PT. Karya Ilmu, 1993

[4] Sukatamsi, Permainan Besar 1 Sepakbola. Jakarta: Departemen Pendidikan dan Kebudayaan, 1994.

[5] E. Kosasih, Pendidikan Jasmani dan Kesehatan. Jakarta: Penerbit Erlangga, 1994

[6] Sukadiyanto, Pengantar Teori Dan Melatih Fisik. Yogyakarta: FIK Universitas Negeri Yogyakarta, 2005.

[7] Harsono, Coching: aspek-aspek Psikologis Dalam Coaching. Jakarta: CV Tambak Kusuma, 1988.

[8] J. Luxbaher, Sepakbola Taktik dan Teknik Bermain. Jakarta Utara: Fajar Interpratama Offset, 1999

[9] R. Lutan, Belajar Ketrampilan Motorik, Pengantar Teori dan Metode. Jakarta: Departemen P\&K Dirjen Dikti Proyek Pengembangan Lembaga Pendidikan dan Tenaga Kependidikan, 1988

[10] S. Arikunto, Metode Penelitian Suatu Pendekatan Praktik. Jakarta: Rineka Cipta, 2010

[11] D.R. Kirkendall, J.J. Gruber and R.E. Johnson, Measurement and evaluation for Physical Educators. USA: Wm. C. Brown Company Publishers, 1980.

[12] Nurhasan, Tes dan Pengukuran dalam Pendidikan Jasmani: PrinsipPrinsip dan Penerapannya. Jakarta, 2001 